ROCZNIKI KULTUROZNAWCZE

Tom X, numer 3 - 2019

DOI: http://dx.doi.org/10.18290/rkult.2019.10.3-3

BŁAŻEJ DYCZEWSKI

\title{
CELE ŻYCIOWE MŁODZIEŻY KOŃCZĄCEJ SZKOŁĘ PODSTAWOWĄ. PRÓBA KLASYFIKACJI WARTOŚCI MŁODEGO POKOLENIA
}

Świat wartości jest integralnym elementem człowieka działającego w polu wzajemnych interakcji - twórcy kultury. Z kolei kultura jest nierozerwalnie związana z życiem człowieka. Jest ona przez niego tworzona we wspólnocie, w trakcie dążenia do realizacji potrzeb, pragnień i działań. Kultura to świat wartości, które ukierunkowują ludzkie pragnienia oraz są podstawą wszystkiego, co człowiek myśli, czego pragnie i co czyni ${ }^{1}$.

Wartości, jako rzeczywista nie zaś domniemana cenność czegokolwiek dla człowieka lub grupy ludzi ${ }^{2}$, są jednym z podstawowych elementów rzeczywistości społecznej i kulturowej ${ }^{3}$, które poprzez swoje zakorzenienie w normach, zwyczajach i obyczajach mają wyraźny wpływ na kształt społeczeństw, przez co wyznaczają pion tożsamości kulturowej każdej grupy społecznej. Dlatego można mówić o swoistej tożsamości kulturowej Polaków, Niemców, Ślązaków, a także Europejczyków, Amerykanów czy też katolików bądź młodzieży lub osób starszych ${ }^{4}$.

W dyskursie publicznym mowa jest najczęściej o kryzysie wartości, którego upatruje się nie tyle w przemianie wartości, co we współistnieniu wielu

Dr BŁAżEJ Dyczewski - Katedra Badań nad Kulturą i Komunikacją w Instytucie Socjologii, Wydział Filozofii i Socjologii Uniwersytetu Marii Curie-Skłodowskiej w Lublinie; adres do korespondencji: Pl. Marii Curie-Skłodowskiej 4, 20-031 Lublin, e-mail: blazej.dyczewski@poczta.umcs. lublin.pl, ORCID: https://orcid.org/0000-0002-6060-3722.

${ }^{1}$ Leon Dyczewski, Kultura w całościowym planie rozwoju (Warszawa: Instytut Wydawniczy Pax, 2011).

${ }^{2}$ Adam RodzińSKI, Na orbitach wartości (Lublin: Redakcja Wydawnictw KUL, 1989), 42.

${ }^{3}$ Józef SтYк, „Orientacje wartościujące współczesnej młodzieży polskiej”, w Problemy wspótczesnej młodzieży w ujęciu nauk społecznych, red. Franciszka W. Wawro (Lublin: Wydawnictwo KUL, 2007), 29-35.

${ }^{4}$ DycZewsKi, Kultura w całościowym planie rozwoju, 42. 
równorzędnych hierarchii wartości, wzajemnie się wykluczających ${ }^{5}$, czy też $\mathrm{w}$ utrzymującej się tendencji do permisywizmu i relatywizmu, redukcji zła i ukazaniu go jako dobra, a także subiektywizacji wzorów osobowych pochodzących $\mathrm{z}$ tradycyjnych systemów etycznych oraz w osłabieniu roli wzorów środowiskowych ${ }^{6}$. Należy jednak zauważyć, że wyznawane przez jednostkę wartości nie są kwestią wyłącznie jej wyboru, lecz uwarunkowane są czynnikami kulturowymi, społecznymi, rodzinnymi, osobowościowymi oraz sytuacyjnymi ${ }^{7}$.

Janusz Mariański podkreśla, że w Europie, co najmniej od lat 80. XX wie$\mathrm{ku}$, ma miejsce epokowa zmiana ludzkości polegająca na przejściu od tradycji do ponowoczesności. Zmiana ta związana jest z dyferencjacją społeczną, której głównym efektem jest konstruowanie własnych systemów znaczeń i interpretacji, a jednostka przynależy do różnych niekiedy konkurencyjnych grup, przez co erozji ulega „przymusowa homogeniczność” grup społecznych. Innym czynnikiem determinującym społeczeństwo ponowoczesne jest deinstytucjonalizacja, polegająca na osłabieniu legitymizacji oraz przełamaniu monopolu tradycyjnych instytucji społecznych, co w konsekwencji prowadzi do osłabienia motywacji społecznej do przejmowania tradycyjnych form życia społecznego, a co za tym idzie osłabienia roli kontroli społecznej jako czynnika wiążącego homogeniczność kulturową członków społeczeństwa. Kolejnym czynnikiem determinującym tę epokową przemianę społeczną jest pluralizm kulturowy, którego nieodłącznym elementem jest mnogość wyznań i religii, wartości, grup społecznych, stylów życia, a także poglądów politycznych, gdzie jednostka społeczna może być przekonana o braku ograniczeń do czegokolwiek. Czwartym czynnikiem jest strukturalny indywidualizm determinujący jednostki do poszukiwania własnej drogi życiowej w oparciu na autonomicznych wyborach i dążeniach do pielęgnowania osobistych potrzeb i aspiracji ${ }^{8}$.

W dzisiejszych pluralistycznych i ponowoczesnych społeczeństwach absolutne pierwszeństwo przyznaje się teraźniejszości, odrywając ją niejako od

\footnotetext{
${ }^{5}$ Władysław ZuZIAK, „Czy aksjologia może przezwyciężyć ponowoczesny kryzys wartości?”, Przegląd Filozoficzny - Nowa Seria 82(2)(2012): 295, https://doi.org/10.2478/v10271-012-0058-6 (dostęp: 12.12.2019).

${ }^{6}$ Janusz MARIAŃSKI, Przemiany moralności polskich maturzystów w latach 1994-2009 (Lublin: Wydawnictwo KUL, 2011); Janusz MARIAŃSKI, Moralność w okresie przemian (Warszawa: Instytut Wydawniczy PAX, 1990).

${ }^{7}$ Piotr OLEŚ, Wartościowanie a osobowość (Lublin: Redakcja Wydawnictw KUL, 1989), 5.

8 Janusz MARIAŃSKI, Młodzież między tradycją a ponowoczesnościa (Lublin: Redakcja Wydawnictw KUL, 1995), 13-38.
} 
dziedzictwa kulturowego przeszłości. W takich społeczeństwach eksperymentowanie w dziedzinie wyborów moralnych jest atrybutem wolności, a działania wielu ludzi uzewnętrzniają i akcentują antywartości, niezwiązane z wartościami i normami bezwzględnymi. Jak podkreśla Janusz Mariański, może to prowadzić, szczególnie u młodych ludzi, do zagubienia i pozbawienia autorytetów, dezinstytucjonalizacji, detradycjonalizacji, pluralizacji oraz indywidualizacji. W konsekwencji wyakcentowane są postawy ukierunkowane na autonomizację decyzji, samorealizację, samoekspresję, kreatywność, niezależność, wiarę w rozwój, jak również partycypację w życiu społecznym

Postępujące procesy pluralizmu społecznego i kulturowego sprzyjają przemianom moralności, a w społeczeństwie polskim można zaobserwować pewne ogólniejsze tendencje, widoczne zwłaszcza wśród młodego pokolenia. Widać tu dokonujący się proces subiektywizacji wzorów pochodzących z tradycyjnych systemów etycznych. Jednak wśród młodzieży słabnie rola środowiskowych wzorów osobowych. Stałość i charakter ogólny zachowują jedynie reguły będące szczególnym przypadkiem dobroczynności i sprawiedliwości, jak na przykład obowiązek wierności małżeńskiej czy też zakaz uciekania się do przemocy ${ }^{10}$.

Artykuł ma charakter empiryczno-socjologiczny i posiada dwa cele. Pierwszym jest próba scharakteryzowania systemu wartości uczniów ósmych klas szkół podstawowych, czyli uczniów kończących edukację na poziomie podstawowym. Cel ten został zrealizowany poprzez statystyczne przedstawienie wskazywanych przez respondentów wartości, które są dla nich cenne w życiu, a opierają się na podstawowych kryteriach społeczno-demograficznych (płeć, sytuacja materialna rodziny respondenta, wielkość miejscowości zamieszkania, stopień zaangażowania religijnego). Drugim celem jest próba zredukowania wymiarów wartości wyrażanych w 28 kategoriach reprezentujących wybrane główne cele życiowe młodzieży do mniejszej grupy wartości. Słowem, sprowadzenie głównych celów życiowych do systemu wartości młodzieży. Cel ten zostanie osiągnięty poprzez przeprowadzenie analizy czynnikowej metodą głównych składowych. Pozwoli to sklasyfikować główne grupy wartości pokolenia opuszczającego szkołę podstawową. Zasadne wydaje się tutaj pytanie, czy wartości ważne dla młodego pokolenia układają się w jakieś bardziej ogólne modele? Dlatego postawiono dwie hipotezy badawcze:

\footnotetext{
${ }^{9}$ Janusz MARIAŃSKI, „Wartości moralne w zmieniającym się społeczeństwie polskim”, Edukacja Humanistyczna 1(24)(2011): 15-17.

10 Janusz MARIAŃSKI, W poszukiwaniu sensu życia: szkice socjologiczno-pastoralne (Lublin: Redakcja Wydawnictw KUL, 1990), 36 i n.
} 
H1: Główne cele życiowe uczniów klas ósmych szkół podstawowych układają się w zhierarchizowany system wartości wyznaczany poprzez takie cechy, jak płeć, sytuacja materialna rodziny, stopień zaangażowania religijnego, a także chociaż w mniejszym stopniu wielkość miejscowości zamieszkania.

H2: Główne cele życiowe uczniów klas ósmych szkół podstawowych, reprezentowane przez 28 kategorii można sprowadzić do mniejszej liczby grup, które można nazwać wartościami, na które młode pokolenie, kończące szkołę podstawową zwraca szczególną uwagę w swoim życiu.

\section{WARTOŚCI SPOŁECZNE A WARTOŚCI KULTUROWE}

Pojęcie wartości jest mocno osadzone w literaturze humanistycznej. O wartościach traktowali już Platon i Arystoteles oraz filozofowie greccy ${ }^{11}$. Pojęcie wartości funkcjonuje w wielu dyscyplinach naukowych: filozofii, socjologii, antropologii kulturowej oraz psychologii społecznej ${ }^{12}$. Filozofia traktuje wartości jako obszar etyki i estetyki, definiując je jako cechę, dzięki której dany przedmiot jest wartościowy ${ }^{13}$. Psychologia odnosi się do wartości jako do czegoś, do czego jednostka dąży ze względu na jej system przekonań, standardy życiowe, które ukierunkowują zachowanie jednostki, a samo definiowanie pojęcia „wartości” często jest odnoszone do postaw, potrzeb, pragnień ${ }^{14}$. W psychologii uznaje się, że wartości wyznaczają sposób zachowania się człowieka $^{15}$, są czynnikiem, który uruchamia ludzką motywację ${ }^{16}$.

$\mathrm{Na}$ gruncie nauk społecznych także funkcjonuje wiele definicji wartości. Najogólniej są one rozumiane jako ,pewne obrazy czy wizje rzeczy, stanów czy procesów pożądanych, uznawanych za właściwe, słuszne, moralne, czy też takie, jakich by się chciało" ${ }^{17}$. „Są także zbiory obiektów, kategorii, idei,

\footnotetext{
${ }^{11}$ Giovanni Reale, Historia filozofii starożytnej (Lublin: Wydawnictwo KUL, 2012).

${ }^{12}$ Maria MiszTal, Problematyka wartości w socjologii (Warszawa: Państwowe Wydawnictwo Naukowe, 1980), 5.

${ }^{13}$ Józef BoCHEŃSKI, Sto zabobonów. Krótki filozoficzny stownik zabobonów (Kraków: Philed Sp. z o.o, 1994), 133.

${ }^{14}$ Misztal, Problematyka wartości w socjologii, 93.

${ }^{15}$ Magdalena KLESZCZ i Małgorzata ŁĄCZYK, Młodzież licealna wobec wartości, samotności i pasji (Kraków-Katowice: Impuls, 2012), 15.

${ }^{16}$ Hanna ŚwIDA-ZIEMBA, Młodzież a wartości (Warszawa: Wydawnictwa Szkolne i Pedagogiczne, 1979), 16.

${ }^{17}$ Stefan NowaK, „Postawy wartości aspiracje społeczeństwa polskiego. Przesłanki i prognozy na tle przemian dotychczasowych", w Społeczeństwo polskie czasu kryzysu, red. Stefan Nowak (Warszawa: Uniwersytet Warszawski, Instytut Socjologii, 1984), 403.
} 
jak również stanów rzeczy, które uruchamiają ludzką motywację"18. Jak zauważa Adam Rodziński, wartość to cenność czegokolwiek, co jest ważne dla różnych grup społecznych, pojedynczych jednostek lub wszystkich ${ }^{19}$. Wartości w socjologicznym znaczeniu posiadają personalny oraz grupowy charakter. Stanowią płaszczyznę porównywania się członków grupy z innymi, są punktem odniesienia dla członków danej społeczności ${ }^{20}$.

Za wartość społeczną w sensie socjologicznym można uznać „wszelki przedmiot posiadający empiryczną treść, dostępną członkom grupy społecznej, oraz znaczenie, wskutek którego jest on lub może być obiektem działalności" ${ }^{21}$. Na gruncie socjologii wartości traktuje się więc jako zewnętrzne wobec jednostki przedmioty o charakterze kulturowym. Wartościami są więc społeczne reguły czy też normy zachowania wywołujące pewne postawy u jednostek oraz pełniące w społeczeństwie funkcję kontrolną ${ }^{22}$. Jednak tutaj uwaga skupiona jest na społecznych uwarunkowaniach wyznawanych przez jednostkę wartości, takich jak pochodzenie społeczne czy pełnione przez jednostkę role. Wartości są więc koncepcją tego, co jest godne pożądania w wymiarze emocjonalnym, poznawczym i wolicjonalnym. Koncepcje te modeluja wybory jednostek spośród dostępnej palety sposobów, środków i celów działania, które muszą uzyskać uzasadnienie moralne, estetyczne lub intelektualne. Tak ukształtowana koncepcja wartości pełni jeszcze jedną istotną funkcję, mianowicie wartości stanowią płaszczyznę odniesienia ludzi lub grup społecznych do siebie, przez co także stanowią czynnik relacji interpersonalnych ${ }^{23}$.

Za autorów socjologicznych definicji wartości, za Marią Misztal, można uznać Floriana Znanieckiego i Williama Thomasa, Clyde'a Kluckhohna, Miltona Rokeacha, Davida Krecha, Richarda Crutchfielda, Egertona Ballacheya oraz Talcotta Parsonsa ${ }^{24}$. Za socjologów ostatniego ćwierćwiecza zajmujących się wartościami należy uznać Janusza Mariańskiego, Hannę Świdę-Ziębę oraz Leona Dyczewskiego. Pierwszy rozpatruje wartości przez pryzmat religii

\footnotetext{
18 ŚWIDA-ZIEMBA, Młodzież a wartości, 16-33.

${ }^{19}$ RODZIŃSKI, Na orbitach wartości, 42.

${ }^{20}$ Anna BŁasıaK, Młodzież - świat wartości (Kraków: Wyższa Szkoła Filozoficzno-Pedagogiczna „Ignatianum”-Wydawnictwo WAM, 2002), 121.

${ }^{21}$ William I. THOMAS i Florian ZNANIECKI, „Praktyka społeczna zdrowego rozsądku a teoria społeczna" (William I. ThomAs, Florian ZNANIECKI, Chłop polski w Europie i Ameryce. Nota metodologiczna (Warszawa: Ludowa Spółdzielnia Wydawnicza, 1976), 41-91), w Marian MALINKOwsKi, Stanisław MARCZuK, red., Socjologia ogólna. Wybór tekstów (Rzeszów: Wydawnictwo Wyższej Szkoły Pedagogicznej w Rzeszowie, 1986), 283.

22 MiszTal, Problematyka wartości w socjologii, 34-35.

${ }^{23}$ Tamże, 34-39.

${ }^{24}$ Tamże, s. 33.
} 
w ogólnym charakterze socjologii moralności Polaków, a także młodzieży, druga, podkreślała rolę czynników społecznych dla kształtowania się sytemu wartości młodego pokolenia, trzeci podkreślał kulturotwórczą rolę wartości głównie kulturowych, które kształtują tożsamość narodową Polaków ${ }^{25}$.

Dla Janusza Mariańskiego wartości stanowią bardziej ogólne i trwałe orientacje określające perspektywy życia codziennego. Wyznaczają także normy odnoszące się do konkretnych zachowań. Wartościami są więc dla niego duchowe, moralne przekonania jednostek lub grup społecznych kierujące ich zachowaniami i postawami. Można powiedzieć, że wartości to jest to wszystko, co wiąże się z pozytywnymi emocjami, co skupia na sobie pragnienia i dążenia człowieka, co jest dla niego ważne i istotne, godne pożądania. Zatem wartościami jest wszystko to, do czego człowiek dąży i pragnie osiągnąć w największym stopniu ${ }^{26}$. Mariański podkreśla, że wartościami w sensie ścisłym są wszelkie normatywne, powinnościowe nastawienia i oczekiwania kierowane wobec różnych przedmiotów sytuacji, zachowań. Zatem pod pojęciem wartości należy także rozumieć wszelkie dawanie wyrazu pożądanym stanom społecznym $^{27}$.

W odniesieniu do wartości Mariański najczęściej posługuje się terminem „wartości moralne”, do których zalicza ogólne orientacje wartościujące, wartości codzienne i ostateczne, prospołeczne i egoistyczne, egzystencjalne, wartości życia małżeńskiego i rodzinnego, wartości godnościowe oraz podstawowe, wskazując jednocześnie na przewartościowanie wartości jako efekt szybko zmieniających się warunków społeczno-kulturowych ${ }^{28}$.

Hanna Świda-Ziemba natomiast definiuje wartości jako kryterium, na podstawie którego można uznać niektóre obiekty jako godne pożądania, jako przedmiot pragnień osadzony w perspektywie doświadczenia ${ }^{29}$. W publikacji

\footnotetext{
${ }^{25}$ Leon DYCZEWSKI, „System wartości w świadomości młodego pokolenia”, Roczniki Nauk Spotecznych 8(3)(1980): 259-271; Leon DYCZEWSKI, „Wartości kulturowe ważne dla polskiej tożsamości”, w Tożsamość polska w odmiennych kontekstach. Tożsamość osób, zbiorowości, instytucji, red. Leon Dyczewski, Dariusz Wadowski (Lublin: Wydawnictwo KUL, 2009); Janusz MARIAŃSKI, „Świadomość moralna Polaków w procesie przemian - główne tendencje”, w Style życia, wartości, obyczaje. Stare tematy, nowe spojrzenia, red. Aldona Jawłowska, Wojciech Pawlik, Barbara Fatyga (Warszawa: Wydawnictwo UW, 2012); MARIAŃSKI, Przemiany moralności polskich maturzystów; ŚWIDA-ZIEMBA, Młodzież a wartości.

${ }^{26}$ MARIAŃSKI, $W$ poszukiwaniu sensu życia, 161-173.

${ }^{27}$ MARIAŃSKI, Młodzież między tradycją, 63.

${ }^{28}$ Tamże, 70-71.

${ }^{29}$ Hanna ŚwIDA-ZIEMBA, Wartości egzystencjalne młodzieży lat dziewięćdziesiatych (Warszawa: Zakład Socjologii Moralności i Aksjologii Ogólnej, Instytut Stosowanych Nauk Społecznych, Uniwersytet Warszawski, 1988), 19.
} 
pod redakcją Hanny Świdy-Ziemby, Andrea Folkierska wyróżnia osiem grup wartości, spośród których pierwszą stanowią wartości intelektualne, związane $\mathrm{z}$ bogactwem treści intelektualnych, pobudzające ich procesy umysłowe ukierunkowane na wiedzę, sprawność działania będącą wynikiem przyswojenia sobie pewnego zakresu wiedzy. Drugie to wartości estetyczne ukierunkowane na sztukę, wrażliwość na piękno, które wykracza poza dobro i zło, a jednocześnie jest źródłem własnych przeżyć estetycznych. Trzecią grupę stanowią wartości socjocentryczne, nastawione na pielęgnowanie idei uważanych przez jednostkę za słuszne, dla których szczęście indywidualne można i należy porzucić, zatracić. Dla jednostki wyrażającej tego typu wartości ważne będą takie idee, jak naród, państwo, dobro ojczyzny, patriotyzm. Wartości socjocentryczne wyrażają się także poprzez obronę idei, które są bliskie jednostce. Mowa jest tutaj o ideach, poglądach realizowanych przez różne grupy, z którymi jednostka się identyfikuje ${ }^{30}$.

Czwarta grupa to wartości allocentryczne, ukierunkowane na dobro człowieka poprzez wrażliwość na ludzką krzywdę i nieszczęście, a także zdolność zrozumienia ich potrzeb i gotowość do niesienia pomocy. Inną grupę wartości (piątą) stanowią wartości prestiżowe wyrażane poprzez dążenie do osiągnięcia wysokiej pozycji społecznej, uznania, władzy i wpływów. Osoby wykazujące tego typu wartości skoncentrowane są na zdobyciu określonej pozycji społecznej, szacunku i dobrej opinii oraz możliwości sprawowania władzy, a także posiadania wpływów. Grupą wartości, do których można zaliczyć manifestację zamożności, są wartości konsumpcyjno-materialne. Do tej grupy można zaliczyć także własny sukces życiowy, wysoki dobrobyt, czyli wszystko to, co jest nastawione na osiągnięcie materialnych korzyści dla siebie lub też osiąganie korzyści materialnych posiadających wysoką rangę społeczną ${ }^{31}$.

Kolejną grupą wartości są wartości przyjemnościowe nastawione na niwelowanie przykrych i uciążliwych stanów psychospołecznych. Są one ukierunkowane są na życie łatwe i bezproblemowe, bez napięć i konfliktów, ale jednocześnie $\mathrm{z}$ bogatą dawką odprężenia pozwalającego zapomnieć o własnych trudnościach i kłopotach. Zgoła odmienne wydają się wartości emocjonalne ukierunkowane na doznawanie silnych przeżyć bez względu na to, czy byłyby one opatrzone emocjami pozytywnymi czy też negatywnymi. Istotą jest sam fakt uniesienia oraz siła tych uczuć. Ostatnią grupę stanowią wartości perfekcjonistyczne stanowiące uzewnętrznienie ludzkich walorów sprawnościowych

\footnotetext{
${ }^{30}$ Andrea FolKIERSKA, „Typy wartości, ich miejsce i funkcjonowanie w kulturze”, w Młodzież a wartości, red. Hanna Świda-Ziemba (Warszawa: Wydawnictwa Szkolne i Pedagogiczne, 1979), 94-97.

${ }^{31}$ Tamże, 98.
} 
pod kątem fizycznym, charakterologicznym (osobowościowym). Osoby wykazujące tego typu wartości będą poszukiwać inspiracji do samodoskonalenia, wzmacniania siły charakteru, budowania niezależności wobec innych, a także doskonalenia sprawności fizycznej lub intelektualnej ${ }^{32}$. Na uwagę zasługuje fakt, że w systemie wartości opracowanym przez Andreę Folkierską brakuje wartości nastawionych na przeżycia duchowe i związane $\mathrm{z}$ nimi idee dobra i zła, sacrum i profanum.

W socjologii zwraca się uwagę, że oprócz wartości grupowych czy też społecznych, będących konceptualizacją pożądanego systemu społecznego, stanowiących swoisty element społecznej ideologii o charakterze normatywnym dla poszczególnych grup społecznych, funkcjonują wartości kulturowe, dominujące w danej kulturze, czyli wyznawane przez wszystkich lub większość członków danego społeczeństwa. Są one zakotwiczone w państwie, narodzie lub szerszych kręgach kulturowych. Są usankcjonowane w danym kręgu kulturowym i istnieją ponad podziałami statusu jednostek czy pełnionej roli społecznej ${ }^{33}$. Wartości kulturowe funkcjonują poza jednostką. Jednostki je poznają, przeżywają i uwewnętrzniają lub realizują na swój własny sposób. Poprzez pozytywne lub negatywne ustosunkowanie się jednostek, wartości określają charakter i jakość kultury każdej grupy społecznej ${ }^{34}$.

Definicje o charakterze kulturowym odnoszą się do trzech grup. Pierwsze traktują wartości jako przedmioty pożądane przez większość lub wszystkich członków danego społeczeństwa. Według Waltera Goldschmidta na wartości w sensie kulturowym składają się trzy komponenty: status (społeczny), rola (społeczna) oraz przedmioty bezpośrednio związane z najwyższymi pozycjami w społeczeństwie, czyli symboliczne przedstawienia, które zawsze występują łącznie i tworzą zjawisko nazwane arete, czyli uniwersalną cechę społeczeństwa ${ }^{35}$.

Druga grupa definicji wskazuje, że wartościami kulturowymi są powszechne w danym społeczeństwie akceptowane przekonania o charakterze egzystencjalno-normatywnym odnoszące się do natury człowieka i jego miejsca w przyrodzie, stosunku człowieka do człowieka, a także tym, co godne i niegodne

\footnotetext{
32 Tamże, 99-100.

${ }^{33}$ Misztal, Problematyka wartości w socjologii, 34-35, 39.

${ }^{34}$ Leon DyCZEwSKI, „Miejsce i funkcje wartości w kulturze”, w Kultura w kręgu wartości, red. Leon Dyczewski (Lublin: Towarzystwo Naukowe KUL, 2001), 32; Leon DyCZEWSKI, Wartości w kulturze polskiej (Lublin: Fundacja Pomocy Szkołom Polskim na Wschodzie im. Tadeusza Goniewicza, 1993), 29.

${ }^{35}$ Walter Goldschmidt, „Values and the Field of Comparative Sociology”, American Sociological Review 18(3)(1951): 287-293.
} 
pożądania. Te swoiste orientacje wartościujące, powszechne w danym społeczeństwie, zawierające zarówno elementy wartościujące, jak i egzystencjalne, są wartościami kulturowymi. Trzecia grupa definicji podkreśla normatywny charakter systemu wartości, które stanowią punkt odniesienia, kryterium, wzorzec przy podejmowanych wyborach jednostki ${ }^{36}$.

Zatem, za Leonem Dyczewskim, można przyjąć, że wartość kulturowa, to wartość społecznie usankcjonowana, typowa dla danej kultury, uwewnętrzniona przez ogót członków społeczeństwa, pomaga im ona dokonywać wyborów, ukierunkowuje i wskazuje cel oraz środki dziatania, a także wzmacnia samo działanie $w$ ramach tej dziedziny społeczno-kulturowej, w której sama tkwi. Istotnymi kryteriami wartości kulturowej są: jej miejsce w kulturowym systemie wartości (kryterium obiektywne) oraz jej rola jako czynnika rozwoju, jej miejsce i rola w życiu i strukturze osobowości jednostek - słowem, na ile wartość przyczynia się do rozwoju jednostki (kryterium subiektywne). Cechą charakterystyczną wartości kulturowych, podobnie jak wartości społecznych, jest ich hierarchiczność. Jedne wartości są bardziej cenne dla danego społeczeństwa, inne mniej ${ }^{37}$.

Wartości rozumiane w sensie kulturowym pojmowane są jako powszechnie uznane i pożądane w danym społeczeństwie wytwory, miejsca, wydarzenia. Są to także powszechnie akceptowane sądy natury egzystencjalno-normatywnej i pewne orientacje wartościujące, np. wartość zdrowia, wiedzy, ojczyzny. Wartościami w sensie kulturowym są także charakterystyczne dla danego społeczeństwa stany psychospołeczne i odpowiadające im zachowania, np. gotowość do niesienia pomocy, gościnność, ofiarność, tolerancja; oraz upowszechnione $\mathrm{w}$ danym społeczeństwie przekonania na temat słuszności danego systemu wartości, norm, wzorów zachowania, będących podstawą życia indywidualnego i zbiorowego, np. chrześcijaństwo, dekalog ${ }^{38}$.

Leon Dyczewski dokonał swoistej klasyfikacji wartości kulturowych społeczeństwa polskiego stanowiących podstawę polskiej tożsamości. Wartości te jako wyraźnie widoczne $\mathrm{w}$ dziedzictwie kulturowym tkwią do dzisiaj w świadomości przeciętnego Polaka, są pielęgnowane, a także przekazywane młodemu pokoleniu. Grupowane są w bardziej ogólne kategorie, spośród których pierwszą stanowią wartości rodzinne i społeczne. Należą do nich rodzinność i poczucie wspólnotowości, dom, żywotna więź pokoleń i silne

\footnotetext{
${ }^{36}$ Tamże, 34-35, 39.

${ }^{37}$ DYCZEWSKI, „Miejsce i funkcje wartości w kulturze”, 32; DYCZEWSKI, „Wartości kulturowe ważne dla polskiej tożsamości”, 152.

${ }^{38}$ DYCZEWSKI, „Wartości kulturowe ważne dla polskiej tożsamości”, 151.
} 
poczucie pokrewieństwa, wysoka wartość dziecka, wysoka pozycja kobiety matki, a także racjonalność dopełniona uczuciowością. Drugą grupę stanowią wartości patriotyczne, do których można zaliczyć wolność - suwerenność patriotyzm, demokrację - obywatelskość - krytycyzm wobec władzy, jak również język polski. Trzecią grupę tworzą wartości społeczne lub też społecznie pożądane do prawidłowego funkcjonowania społeczeństwa. Do tych wartości można zaliczyć otwartość na inne kultury, intymność otwartą, a także gościnność oraz indywidualizm uspołeczniony. Czwartą grupę mogą tworzyć wartości ukierunkowane na wiarę w Boga i religijność. Do tej grupy można zaliczyć właśnie religijność, nadzieję ponad realizm - łatwowierność, a także brak mściwości, łatwość przebaczania ${ }^{39}$.

\section{METODA I DOBÓR PRÓBY}

Materiał badawczy wykorzystany do niniejszego artykułu stanowi część ogólnopolskich badań realizowanych przez Stowarzyszenie Producentów i Dziennikarzy Radiowych w ramach Społecznej Diagnozy Uczniów 2018 „Lustro”. Badaną grupę stanowili uczniowie szkół podstawowych z samorządów biorących udział w kampanii „Zachowaj Trzeźwy Umysł 2018”. Do badań ankietowych przystąpiły dzieci i młodzież z czterech poziomów klas szkół podstawowych (V-VIII klasa). W badaniu wzięli udział uczniowie z ok. 294 gmin z terenu Polski. Liczba przebadanych uczniów wynosiła 70185 (35 983 dziewcząt i 34202 chłopców). Oznacza to, że próba uczniów uczestniczących w badaniach stanowiła 4,14\% populacji klas V-VIII w roku szkolnym 2018/ 2019. Badanie było realizowane za pomocą autorskiego kwestionariusza ankiety internetowej (CAWI) wypełnianego audytoryjnie w dniach 1.10.2018 r. 12.01.2019 r.

Mimo że przebadano dużą grupę młodzieży, próba ta nie była reprezentatywna wobec populacji młodzieży polskiej $\mathrm{w}$ tym wieku względem takich cech, jak: płeć, miejsce zamieszkania (wieś lub miasto) oraz województwo zamieszkania. W celu dopasowania próby badawczej do populacji względem wyżej wymienionych cech przeprowadzono procedurę wyłączenia $\mathrm{z}$ analizy odpowiedniej liczby osób z podgrup, które były nadmiernie reprezentowane. Dane na temat populacji zaczerpnięto $\mathrm{z}$ danych statystycznych udostępnionych przez Ministerstwo Edukacji Narodowej na stronie https://dane.gov.pl stan na dzień 19.03.2019 r. Zestawienie zawierało liczebność uczniów wg klas

\footnotetext{
${ }^{39}$ Tamże, $159-178$.
} 
w podziale na typy szkół, kategorię uczniów (młodzież/dorośli), poziom klasy oraz województwa. Dopasowanie struktury grupy badanych osób do struktury populacji odniesienia polegało na krokowym odlosowaniu jednej osoby z tabeli liczebności otrzymanych zawsze z komórki o największej wartości nadmiaru w stosunku do liczebności oczekiwanej. Po każdorazowym odlosowaniu ponownie obliczano liczebności oczekiwane dla zmniejszonej populacji badanej oraz liczebności nadmiarów lub niedomiarów, jak również związaną $\mathrm{z}$ nimi wartość $\chi^{2}$. Odlosowanie $\mathrm{z}$ próby wykonywano do momentu, gdy wartość $\chi^{2}$ zgodności osiągnęła $p=0,051$. W efekcie końcowym, na potrzeby niniejszego artykułu wyodrębniono reprezentatywną próbę badawczą obejmującą grupę 1986 uczniów klas ósmych szkół podstawowych. Dokładne dane społeczno-demograficzne przedstawia tabela 1.

Tabela 1. Badana młodzież wg płci, wielkości miejscowości zamieszkania, sytuacji materialnej rodziny, województwa

\begin{tabular}{|c|c|c|c|}
\hline & & $\mathrm{N}$ & $\%$ \\
\hline \multirow[t]{2}{*}{ Płeć } & Dziewczynka & 971 & 48,9 \\
\hline & Chłopiec & 1015 & 51,1 \\
\hline \multirow[t]{5}{*}{ Wielkość miejscowości } & Wieś & 733 & 36,9 \\
\hline & Miasto do 20 tys. & 187 & 9,4 \\
\hline & Miasto 20-50 tys. & 543 & 27,3 \\
\hline & Miasto $50-100$ tys. & 276 & 13,9 \\
\hline & Miasto 100 tys. i więcej & 247 & 12,4 \\
\hline \multirow{5}{*}{$\begin{array}{l}\text { Sytuacja materialna rodziny } \\
\text { respondenta }\end{array}$} & Bardzo dobra & 670 & 33,7 \\
\hline & Dobra & 967 & 48,7 \\
\hline & Średnia & 304 & 15,3 \\
\hline & Zła & 16 & 0,8 \\
\hline & Bardzo zła & 29 & 1,5 \\
\hline \multirow[t]{8}{*}{ Województwo } & dolnośląskie & 139 & 7,0 \\
\hline & kujawsko-pomorskie & 107 & 5,4 \\
\hline & lubelskie & 108 & 5,4 \\
\hline & lubuskie & 53 & 2,7 \\
\hline & łódzkie & 122 & 6,1 \\
\hline & małopolskie & 181 & 9,1 \\
\hline & mazowieckie & 303 & 15,3 \\
\hline & opolskie & 44 & 2,2 \\
\hline
\end{tabular}




\begin{tabular}{l|r|r}
\hline podkarpackie & 111 & 5,6 \\
\hline podlaskie & 57 & 2,9 \\
\hline pomorskie & 132 & 6,6 \\
\hline śląskie & 219 & 11,0 \\
\hline świętokrzyskie & 61 & 3,1 \\
\hline warmińsko-mazurskie & 74 & 3,7 \\
\hline wielkopolskie & 190 & 9,6 \\
\hline zachodniopomorskie & 85 & 4,3 \\
\hline
\end{tabular}

Źródło: obliczenia własne

\section{WYNIKI BADAŃ I ICH INTERPRETACJA}

W celu zidentyfikowania grup wartości uważanych przez respondentów za ważne w ich życiu, postawiono im pytanie: Co jest dla Ciebie najważniejsze $w \dot{z} y c i u$ ? Przedstawiono 28 różnych wartości, spośród których respondenci mogli zaznaczyć maksymalnie siedem, które są dla nich najważniejsze. Dane empiryczne dla ogółu badanych przedstawia tabela 2 .

Tabela 2. Najważniejsze wartości w życiu młodzieży

\begin{tabular}{lr|r} 
Najważniejsze wartości w życiu młodzieży & $\mathrm{N}$ & $\%$ \\
\hline Przyjaciele & 1112 & 56,0 \\
\hline Dobra praca w dorosłym życiu & 1095 & 55,1 \\
\hline Miłość na całe życie & 1086 & 54,7 \\
\hline Rozwijanie swoich zainteresowań/hobby & 993 & 50,0 \\
\hline Dobre wykształcenie & 757 & 38,1 \\
\hline Dobre zdrowie & 591 & 29,8 \\
\hline Posiadanie dużych pieniędzy & 545 & 27,4 \\
\hline Moja obecna rodzina & 475 & 23,9 \\
\hline Bóg & 475 & 23,9 \\
\hline Uczciwość & 457 & 23,0 \\
\hline Sprawiedliwość & 414 & 20,8 \\
\hline Udane życie osobiste & 362 & 18,2 \\
\hline Szacunek u innych ludzi & 333 & 16,8 \\
\hline Rozrywka, zabawa & 298 & 15,0 \\
\hline Życie pełne przygód i wrażeń & 281 & 14,1 \\
\hline
\end{tabular}




\begin{tabular}{lr|r}
\hline Sprawność fizyczna & 271 & 13,6 \\
\hline Wyjazdy, podróże & 252 & 12,7 \\
\hline Posiadanie dzieci w przyszłości & 226 & 11,4 \\
\hline Poczucie bycia przydatnym, potrzebnym & 221 & 11,1 \\
\hline Spokój w życiu & 201 & 10,1 \\
\hline Patriotyzm, dobro ojczyzny & 178 & 9,0 \\
\hline Spełnienie ambicji rodziców/opiekunów & 175 & 8,8 \\
\hline Nadzieja & 155 & 7,8 \\
\hline Otwartość na innych & 130 & 6,5 \\
\hline Poszanowanie innych ludzi & 122 & 6,1 \\
\hline Zdolność przebaczania & 119 & 6,0 \\
\hline Wolność głoszenia własnych poglądów & 111 & 5,6 \\
\hline Możliwość angażowania się w życie społeczne & 35 & 1,8 \\
\hline
\end{tabular}

Źródło: obliczenia własne

Można powiedzieć, że młodzież klas ósmych na pierwszym miejscu stawia wartości rodzinne i przyjemnościowe nastawione nie tyle na niwelowanie przykrych stanów psychospołecznych, co dążenie do przyjemności w aspekcie społeczno-indywidualnym. Zatem na pierwszym miejscu znalazła się przyjaźń (56,0\%), na trzecim miłość (54,7\%), na drugim dobra praca w dorosłym życiu $(55,1 \%)$. Spośród badanych co drugi pragnie rozwijać swoje zainteresowania $(50,0 \%)$, a $38,1 \%$ pragnie dobrego wykształcenia. Spośród badanych mniej niż co trzeci pragnie dobrego zdrowia $(29,8 \%)$, dużych pieniędzy $(27,4 \%)$. Mniej więcej co czwarty ankietowany zwraca uwagę na swoją obecną rodzinę (23,9\%) oraz wartość najwyższą - Boga $(23,9 \%)$, a także uczciwość $(23,0 \%)$, w mniejszym stopniu na sprawiedliwość $(20,8 \%)$.

Rzadziej niż wartości wyższego rzędu ankietowani cenią sobie wartości, które można by określić prestiżowymi, do których zalicza się udane życie osobiste $(18,2 \%)$, szacunek u innych ludzi $(16,8 \%)$, rozrywkę i zabawę $(15,0 \%)$, czy też życie pełne przygód i wrażeń $(14,1 \%)$, sprawność fizyczną $(13,6 \%)$, jak również wyjazdy i podróże $(12,7 \%)$. Z kolei posiadanie dzieci w przyszłości cenione jest przez co dziewiątego respondenta $(11,4 \%)$, podobnie jak poczucie bycia przydatnym, potrzebnym $(11,1 \%)$ oraz spokój w życiu $(10,1 \%)$, czy też spełnienie ambicji rodziców lub opiekunów $(8,8 \%)$.

Wartości, które można by zaliczyć do wartości społecznych oraz patriotycznych, cenione są przez respondentów najrzadziej. Dla mniej więcej co trzynastego ucznia ważna jest nadzieja (7,8\%). Mniej więcej co dwunasty ceni 
sobie otwartość na innych $(6,5 \%)$, poszanowanie innych $(6,1 \%)$ czy zdolność przebaczania $(6,0 \%)$. Jakkolwiek dla co jedenastego ucznia cenny jest patriotyzm i dobro ojczyzny $(9,0 \%)$, to wolność głoszenia własnych poglądów ceni sobie co dwudziesty ankietowany $(4,6 \%)$, a co pięćdziesiąty piąty możliwość angażowania się w życie społeczne $(1,8 \%)$.

Jeżeli chodzi preferowane przez młodzież wartości ze względu na płeć, to można powiedzieć, że dziewczęta częściej niż chłopcy podkreślają rolę wartości przyjacielskich - miłość na całe życie (dziewczęta - 59,8\%; chłopcy $49,8 \%$ ) oraz przyjaźń (dziewczęta - 63,2\%; chłopcy - 49,1\%), rodzinnych moja obecna rodzina (dziewczęta - 28,5\% ; chłopcy - 19,5\%), posiadanie dzieci w przyszłości (dziewczęta - 15,0\%; chłopcy - 7,9\%). Poza tym dziewczęta przykładają większą uwagę do dobrego zdrowia (dziewczęta - 34,5\%; chłopcy-25,2\%), wyjazdów i podróży (dziewczęta - 16,3\%; chłopcy - 9,3\%), a także do wartości społecznych takich, jak poczucie bycia przydatnym (dziewczęta - 14,0\%; chłopcy - 8,4\%), otwartość na innych (dziewczęta - 8,3\%; chłopcy $-4,8 \%$ ) czy też zdolność przebaczania (dziewczęta - 7,5\%; chłopcy - 4,5\%) i możliwość angażowania się w życie społeczne (dziewczęta - 6,7\%; chłopcy $-4,5 \%$ ).

Z kolei chłopcy wyżej niż dziewczęta cenią sobie wartości materialne, takie jak dobra praca $\mathrm{w}$ dorosłym życiu (dziewczęta - 52,3\%; chłopcy - 57,9\%) oraz posiadanie dużych pieniędzy (dziewczęta - 22,7\%; chłopcy - 32,0\%). Przez chłopców wyżej cenione są także wartości witalno-hedonistyczne, do których można zaliczyć rozrywkę, zabawę (dziewczęta - 12,7\%; chłopcy 17,2\%) oraz sprawność fizyczną (dziewczęta - 9,6\%; chłopcy - 17,5\%), jako swoisty perfekcjonizm. Warto podkreślić, że chłopcy częściej cenią sobie wartości patriotyczno-religijne, spośród których można wymienić patriotyzm, dobro ojczyzny (dziewczęta - 6,7\%; chłopcy - 11,1\%) oraz Boga (dziewczęta $-19,7 \%$; chłopcy $-28,0 \%$ ).

Jeżeli chodzi o różnice wyznaczane przez zmienną ocena sytuacji materialnej rodziny respondenta, to warto podkreślić, że uczniowie z rodzin najlepiej sytuowanych częściej niż pozostali cenią sobie wartości materialne dobra praca w dorosłym życiu (bardzo dobra - 59,0\%; dobra - 55,2\%; średnia $-48,7 \%$; zła $-50,0 \%$; bardzo zła - 34,5\%), a także służące rozwojowi swoich zainteresowań czy też hobby (bardzo dobra $-48,5 \%$; dobra $-50,4 \%$; średnia - 54,3\%; zła - 62,5\%; bardzo zła - 20,7\%). Respondenci określający swoje warunki materialne na poziomie dobrym częściej niż pozostali podkreślają rolę takich celów życiowych, jak przyjaźn $(60,0 \%)$ i rozwijanie swoich zainteresowań $(50,4 \%)$. Z kolei ankietowani z rodzin o średnim statusie majątkowym 
(54,3\%) znacznie częściej niż respondenci najubożsi (20,7\%) wskazują na chęć rozwijania swoich zainteresowań i pasji. Jakkolwiek respondenci z rodzin najuboższych, wśród siedmiu możliwych do zaznaczenia wartości, częściej podkreślają Boga (bardzo dobra - 28,1\%; dobra - 22,6\%; średnia 17,4\%; zła $-31,3 \%$; bardzo zła $-34,5 \%$ ) oraz nadzieję (bardzo dobra $-6,7 \%$; dobra $-7,2 \%$; średnia - 10,2\%; zła $-6,3 \%$; bardzo zła $-27,6 \%$ ), to także częściej wskazują na rozrywkę i zabawę (bardzo dobra - 15,2\%; dobra $14,6 \%$; średnia - 13,5\%; zła - 25,0\%; bardzo zła - 34,5\%).

Jeżeli chodzi o zmienną niezależną wielkość miejscowości zamieszkania, to warto podkreślić trzy sprawy. Po pierwsze, wraz ze wzrostem liczby mieszkańców rośnie w opinii badanych sfera sacrum. Spośród ankietowanych mieszkańców wsi na Boga wskazuje 30,2\%, podczas gdy wśród mieszkańców małych miast (do 20 tys.) 24,6\%, wśród mieszkańców miast średnich 18,4\%, natomiast wśród mieszkańców miast dużych 19,9\%, a wśród mieszkańców miast bardzo dużych $21,5 \%$. Druga kwestia, którą warto podkreślić, jeżeli chodzi o wielkość miejscowości zamieszkania, to udane życie osobiste, na które większą uwagę zwracają mieszkańcy miast średnich (wieś - 17,9\%; miasto do 20 tys. $-17,1 \%$; miasto $20-50$ tys. $-21,4 \%$; miasto $50-100$ tys. $-18,5 \%$; miasto 100 tys. i więcej-13,0\%). Po trzecie, wraz ze wzrostem wielkości miejscowości zamieszkania respondentów słabnie rola wartości patriotycznych. Wskaźnik dla mieszkańców wsi kształtuje się na poziomie $11,3 \%$, podczas gdy dla mieszkańców miast do 20 tys. na poziomie 9,6\%, wśród mieszkańców miast 20-50 tys. na poziomie 8,3\%, z kolei wśród mieszkańców miast dużych (50-100 tys.) na poziomie 7,6\%, a wśród mieszkańców miast największych (100 tys. i więcej) na poziomie 4,5\%.

Jeżeli chodzi o zmienną niezależną stopień zaangażowania religijnego, to osoby deklarujące się jako niewierzące podkreślały udane życie osobiste $(23,0 \%)$, rozrywkę i zabawę $(22,2 \%)$, a także poczucie bycia przydatnym, potrzebnym $(17,5 \%)$ oraz poszanowanie innych ludzi $(9,3 \%)$ czy wolność głoszenia własnych poglądów $(14,4 \%)$. Z kolei respondenci, którzy zadeklarowali praktykującą wiarę religijną, częściej od pozostałych wskazywali na przyjaźń $(57,2 \%)$, miłość na całe życie $(56,8 \%)$, dobre zdrowie $(31,8 \%)$, a także rodzinę $(26,7 \%)$ oraz Boga $(38,1 \%)$. Poza tym respondenci wierzący i praktykujący częściej od pozostałych wskazywali na posiadanie dzieci w przyszłości $(13,4 \%)$, a także patriotyzm i dobro ojczyzny (11,6\%). Respondenci deklarujący się jako wierzący, lecz niepraktykujący obok wartości rodzinnych, takich jak miłość na całe życie $(57,7 \%)$, obecna rodzina $(23,3 \%)$, równie często wskazywali na przyjaciół $(58,0 \%)$, rozwijanie swoich zainteresowań/ 
hobby $(56,9 \%)$, a także dobre zdrowie $(30,9 \%)$, posiadanie dużych pieniędzy (30,9\%), udane życie osobiste $(20,9 \%)$, rozrywkę i zabawę $(16,7 \%)$ oraz życie pełne przygód i wrażeń (16,5\%). Osoby znajdujące się w tej kategorii wiary religijnej wyżej cenią sobie poczucie bycia przydatnym, potrzebnym $(13,3 \%)$ niż Boga $(9,0 \%)$.

W celu poszukiwania ukrytych wymiarów i struktur w związkach między wymienionymi zmiennymi posłużono się analizą czynnikową metodą głównych składowych. Tę metodę można zastosować także w przypadku zmiennych dychotomicznych pod warunkiem, że każda zmienna zawiera informację o innej cesze. Analiza głównych składowych z wykorzystaniem zmiennych dychotomicznych daje zwykle użyteczne wyniki ${ }^{40}$. W tym przypadku zmienne są kodowane w sposób dychotomiczny, gdzie „1” oznacza, że respondent zaznaczył daną odpowiedź, a „0", że danej odpowiedzi nie zaznaczył. Pozwoli to na dokonanie transformacji 28 wartości w przestrzeń o zredukowanym wymiarze metodą głównych składowych ${ }^{41}$. Założono, że pewne czynniki, czyli wartości wskazywane przez ankietowanych, są przez nich postrzegane wspólnie, mimo że opisują różne wartości i cele życiowe. Analiza czynnikowa pozwoli zredukować liczbę 28 wskaźników do optymalnej liczby zmiennych ukrytych, które w wystarczający sposób pozwolą na wyjaśnienie powiązań między wieloma zmiennymi obserwowalnymi.

W wyniku przeprowadzenia obliczeń dla 28 wskaźników otrzymano przeciętny stopień dopasowania zbioru danych do założeń analizy czynnikowej, mierzony statystyką K-M-O, który dla całego zbioru danych osiągnął wartość 0,640 , co zgodnie $\mathrm{z}$ interpretacją można określić jako przeciętny i wskazuje na przeciętą, jednak akceptowalną adekwatność zbioru danych do założeń analizy czynnikowej ${ }^{42}$. Statystyka $\chi^{2}$ przyjęła wartość 2504,363 , a odpowiadająca jej istotność, przy liczbie stopni swobody 378, kształtowała się na poziomie 0,000 , co pozwala stwierdzić, że macierz korelacji istotnie różni się od macierzy jednostkowej ${ }^{43}$.

\footnotetext{
${ }^{40}$ Jarosław GóRNIAK, „Analiza czynnikowa”, ASK (7)(1998): 85.

${ }^{41}$ Małgorzata Rószkiewicz, Analiza klienta (Kraków: SPSS Polska, 2011), 134.

${ }^{42}$ GÓRNIAK, „Analiza czynnikowa”, 100.

${ }^{43}$ RószKiewicz, Analiza klienta, 37-46.
} 
Tabela 3. Testy Kaisera-Mayera-Olkina i Bartletta

Testy Kaisera-Mayera-Olkina i Bartletta

\begin{tabular}{llr}
\hline Miara KMO adekwatności doboru próby & 0,640 \\
\hline Test sferyczności Bartletta & Przybliżone $\chi^{2}$ & 2504,363 \\
\cline { 2 - 3 } & df & 378 \\
\cline { 2 - 3 } & Istotność & 0,000 \\
\hline
\end{tabular}

Źródło: obliczenia własne

Decyzję o wyborze optymalnej liczby czynników podjęto na podstawie kryterium Kaisera, które wskazuje, że do dalszej analizy należy wykorzystać dziewięć pierwszych czynników o wartościach własnych powyżej 1 (tabela 4$)^{44}$. Czynniki te wyjaśniają łącznie $44,26 \%$ wariancji wszystkich 28 zmiennych.

Tabela 4. Całkowita wyjaśniona wariancja

\begin{tabular}{|c|c|c|c|c|c|c|c|c|c|}
\hline \multirow[b]{2}{*}{ Składowa } & \multicolumn{3}{|c|}{ Początkowe wartości własne } & \multicolumn{3}{|c|}{$\begin{array}{l}\text { Sumy kwadratów ładunków } \\
\text { po wyodrębnieniu }\end{array}$} & \multicolumn{3}{|c|}{$\begin{array}{c}\text { Sumy kwadratów ładunków } \\
\text { po rotacji }\end{array}$} \\
\hline & Ogółem & $\begin{array}{c}\% \\
\text { wa- } \\
\text { riancji }\end{array}$ & $\begin{array}{c}\% \\
\text { skumu- } \\
\text { lowany }\end{array}$ & Ogółem & $\begin{array}{c}\% \\
\text { wariancji }\end{array}$ & $\begin{array}{c}\% \\
\text { skumulowany }\end{array}$ & Ogółem & $\begin{array}{c}\% \\
\text { wariancji }\end{array}$ & $\begin{array}{c}\% \\
\text { skumulowany }\end{array}$ \\
\hline 1 & 2,065 & 7,375 & 7,375 & 2,065 & 7,375 & 7,375 & 1,615 & 5,768 & 5,768 \\
\hline 2 & 1,779 & 6,353 & 13,728 & 1,779 & 6,353 & 13,728 & 1,567 & 5,596 & 11,365 \\
\hline 3 & 1,432 & 5,114 & 18,842 & 1,432 & 5,114 & 18,842 & 1,458 & 5,206 & 16,571 \\
\hline 4 & 1,388 & 4,958 & 23,800 & 1,388 & 4,958 & 23,800 & 1,430 & 5,108 & 21,678 \\
\hline 5 & 1,323 & 4,725 & 28,525 & 1,323 & 4,725 & 28,525 & 1,338 & 4,779 & 26,457 \\
\hline 6 & 1,193 & 4,260 & 32,786 & 1,193 & 4,260 & 32,786 & 1,307 & 4,668 & 31,125 \\
\hline 7 & 1,114 & 3,978 & 36,764 & 1,114 & 3,978 & 36,764 & 1,283 & 4,581 & 35,706 \\
\hline 8 & 1,062 & 3,794 & 40,558 & 1,062 & 3,794 & 40,558 & 1,206 & 4,306 & 40,012 \\
\hline 9 & 1,037 & 3,704 & 44,262 & 1,037 & 3,704 & 44,262 & 1,190 & 4,250 & 44,262 \\
\hline
\end{tabular}

Metoda wyodrębniania czynników - głównych składowych

Źródło: obliczenia własne

\footnotetext{
${ }^{44}$ Tamże, 41.
} 
Tabela 5. Macierz rotowanych składowych

\begin{tabular}{|c|c|c|c|c|c|c|c|c|c|}
\hline & \multicolumn{9}{|c|}{ Składowa } \\
\hline & $\mathrm{F} 1$ & $\mathrm{~F} 2$ & F3 & $\mathrm{F} 4$ & F5 & F6 & F7 & F8 & F9 \\
\hline Uczciwość & 0,635 & 0,144 & $-0,097$ & $\mid 0,116$ & $|0,012|$ & $2 \mid-0,019$ & $-0,034$ & 0,022 & $-0,089$ \\
\hline Sprawiedliwość & 0,582 & $\mid 0,052$ & $-0,132$ & $|-0,057|$ & $|-0,024|$ & $4|0,044|$ & 0,042 & 0,123 & $\mid 0,080$ \\
\hline Nadzieja & 0,569 & $-0,160 \mid$ & $\mid 0,014$ & $\mid 0,097$ & $|-0,034|$ & $4 \mid-0,078$ & $-0,051$ & $-0,114$ & $+\mid-0,039$ \\
\hline Zdolność przebaczania & 0,422 & $-0,155$ & $-0,045$ & $|-0,024|$ & $|0,049|$ & $9 \mid-0,054$ & $-0,036$ & $-0,178$ & $\mid 0,249$ \\
\hline Dobre wykształcenie & $-0,069$ & $\mathbf{0 , 6 3 5}$ & $-0,105$ & $|0,074|$ & $|-0,092|$ & $2 \mid-0,136$ & $-0,090$ & 0,002 & 0,016 \\
\hline Rozwijanie swoich zainteresowań & 0,055 & $\mid \mathbf{0 , 6 2 9}$ & 0,080 & $|0,158|$ & $|-0,019|$ & $9 \mid 0,159$ & $-0,063$ & $-0,039$ & $\mid-0,051$ \\
\hline Dobra praca w dorosłym życiu & $-0,171$ & $\mathbf{0 , 3 5 7}$ & $-0,236$ & $|0,289|$ & $|-0,236|$ & $6|-0,251|$ & $-0,080$ & 0,073 & $\mid 0,031$ \\
\hline $\begin{array}{l}\text { Spełnienie ambicji } \\
\text { rodziców/opiekunów }\end{array}$ & $-0,111$ & $\mathbf{0 , 2 7 4}$ & $-0,245$ & $-0,028$ & $-0,080 \mid$ & $0-0,083$ & $-0,126$ & $-0,271$ & $-0,211$ \\
\hline Życie pełne przygód i wrażeń & $-0,034$ & $-0,010 \mid$ & 0,706 & $-0,029$ & $|-0,011|$ & $1 \mid 0,068$ & 0,018 & $\mid-0,108$ & $3 \mid-0,011$ \\
\hline Wyjazdy, podróże & $-0,124$ & $|0,056|$ & $\mathbf{0 , 6 0 7}$ & $|-0,004|$ & $|0,086|$ & $6|-0,022|$ & $-0,094$ & 0,025 & 0,030 \\
\hline Rozrywka, zabawa & $-0,084$ & $\mid-0,227$ & 0,452 & $-0,006$ & $|-0,246|$ & $6 \mid-0,024$ & $-0,058$ & 0,227 & |-0,068 \\
\hline Miłość na całe życie & 0,031 & 0,129 & $-0,099$ & $\mathbf{0 , 7 3 5}$ & $0,031 \mid$ & $1 \mid 0,038$ & 0,084 & $-0,074$ & $+-0,053$ \\
\hline Przyjaciele & 0,278 & \begin{tabular}{|l|}
0,264 \\
\end{tabular} & 0,161 & 0,609 & 0,019 & $9 \mid-0,014$ & 0,010 & $\mid 0,082$ & $\mid 0,090$ \\
\hline Moja obecna rodzina & $-0,047$ & $\mid 0,024$ & 0,007 & $|-0,016|$ & $\mathbf{0 , 7 0 7}$ & $7-0,078$ & $-0,011$ & 0,102 & $\mid-0,036$ \\
\hline Posiadanie dużych pieniędzy & $-0,288$ & $|0,198|$ & $-0,043$ & 0,132 & $|-0,504|$ & $\mid-0,168$ & $-0,177$ & $-0,058$ & $\mid-0,042$ \\
\hline Posiadanie dzieci w przyszłości & $-0,248$ & $-0,191$ & $-0,121$ & 0,310 & $\mathbf{0 , 4 5 4}$ & 0,053 & $-0,120$ & $-0,060$ & $\mid 0,011$ \\
\hline $\begin{array}{l}\text { Możliwość angażowania się } \\
\text { w życie społeczne }\end{array}$ & $-0,075$ & $-0,031$ & $-0,097$ & 0,058 . & $-0,084$ & $\mathbf{0 , 5 7 5}$ & 0,062 & 0,010 & $\mid-0,014$ \\
\hline $\begin{array}{l}\text { Poczucie bycia przydatnym, } \\
\text { potrzebnym }\end{array}$ & $-0,076$ & 0,035 & 0,000 & 0,072 & 0,043 & $\mathbf{0 , 5 6 7}$ & $-0,107$ & 0,083 & 0,261 \\
\hline $\begin{array}{l}\text { Wolność głoszenia własnych } \\
\text { poglądów }\end{array}$ & 0,048 & $|0,002|$ & 0,122 & $-0,104$ & $|0,068|$ & $\mid \mathbf{0 , 5 3 8}$ & 0,014 & $-0,076$ & $\mid-0,091$ \\
\hline Patriotyzm, dobro ojczyzny & $-0,054$ & $|-0,027|$ & $-0,001$ & 0,026 & $|-0,101|$ & $|0,139|$ & 0,769 & 0,064 & $+0,036$ \\
\hline Bóg & $-0,021$ & $|-0,172|$ & $-0,125$ & 0,047 & $|0,140|$ & $-0,175$ & 0,673 & $-0,022$ & $-0,039$ \\
\hline Dobre zdrowie & $-0,081$ & $-0,017$ & 0,006 & 0,169 & 0,343 & $-0,123$ & 0,009 & 0,565 & $-0,058$ \\
\hline Szacunek u innych ludzi & 0,038 & $|0,224|$ & $-0,083$ & $|-0,232|$ & $|0,085|$ & $|0,078|$ & 0,081 & 0,482 & 0,219 \\
\hline Spokój w życiu & 0,079 & $|-0,229|$ & $-0,110$ & $|-0,094|$ & $|-0,101|$ & $|0,304|$ & $-0,077$ & $\mathbf{0 , 4 7 3}$ & $-0,200$ \\
\hline Sprawność fizyczna & $-0,115$ & $-0,055$ & 0,323 & 0,030 & $\mid-0,083$ & $\mid-0,147$ & 0,004 & $\mathbf{0 , 4 0 4}$ & $-0,038$ \\
\hline Otwartość na innych & 0,073 & $|-0,024|$ & 0,020 & 0,003 & $-0,053$ & $|0,002|$ & 0,033 & $-0,041$ & $\mathbf{0 , 6 3 8}$ \\
\hline Udane życie osobiste & $-0,144$ & $|-0,262|$ & $-0,089$ & 0,225 & $|-0,118|$ & $3|-0,019|$ & $-0,311$ & 0,115 & $\mathbf{0 , 5 0 1}$ \\
\hline Poszanowanie innych ludzi & 0,044 & 0,260 & $-0,003$ & $-0,312$ & $|0,177|$ & 7| $0,099 \mid$ & 0,076 & $-0,012$ & 0,462 \\
\hline
\end{tabular}

Metoda wyodrębniania czynników - Głównych składowych

Metoda rotacji - Varimax z normalizacją Kaisera

a. Rotacja osiągnęła zbieżność w 15 iteracjach

Źródło: obliczenia własne 
Na podstawie analizy czynnikowej 28 wskaźników określających główne cele życiowe młodzieży wyodrębniono dziewięć głównych składowych, które można interpretować jako dziewięć głównych grup wartości, czy też celów życiowych młodzieży (tabela 5). Pierwszy model (F1) wyjaśniający 7,37\% określono jako wartości allocentryczno-etyczne, silnie powiązane z takimi wskaźnikami, jak: uczciwość, sprawiedliwość, nadzieja, zdolność przebaczania. Druga grupa (F2), wyjaśniająca $6,35 \%$ wariancji, to wartości konsumpcyjno-materialno-intelektualne, które są silnie powiązane $\mathrm{z}$ dobrym wykształceniem, rozwijaniem swoich zainteresowań i hobby, dobrą pracą w dorosłym życiu, ale także ze spełnianiem ambicji swoich rodziców lub opiekunów. Trzeci model (F3) wyjaśnia 5,11\% wariancji i reprezentuje grupę wartości hedonistycznych silnie powiązanych z takimi wskaźnikami, jak życie pełne przygód i wrażeń, wyjazdy i podróże oraz rozrywka i zabawa. Grupa czwarta (F4) wyjaśniająca 4,96\% wariancji składająca się tylko z dwóch wskaźników (miłość na całe życie, przyjaciele), to grupa wartości przyjemnościowych. Grupa piąta (F5), która wyjaśnia 4,72\% wariancji, to wartości rodzinne, do których należą takie cele życiowe, jak obecna rodzina respondenta oraz posiadanie dzieci w przyszłości, jak również brak przymusu posiadania dużych pieniędzy. Grupa szósta (F6) wyjaśnia 4,26\% wariancji. Są to wartości socjocentryczno-utylitarne, silnie powiązane $\mathrm{z}$ takimi wskaźnikami, jak możliwość angażowania się w życie społeczne, poczucie bycia przydatnym, potrzebnym, a także wolność głoszenia własnych poglądów. Grupa siódma (F7) wyjaśniająca 3,98\% wariancji, to wartości religijno-patriotyczne, silnie powiązane z takimi wskaźnikami, jak patriotyzm, dobro ojczyzny, a także Bóg. Przedostatnią grupę (F8) wyjaśniającą 3,79\% wariancji stanowią wartości perfekcjonistyczno-witalne, silnie powiązane z takimi wskaźnikami, jak dobre zdrowie, szacunek u innych, spokój w życiu oraz sprawność fizyczna. Ostatnią grupę (F8), która wyjaśnia 3,70\% wariancji reprezentują wartości społecznie-pożądane, które są reprezentowane przez takie wskaźniki, jak otwartość na innych, udane życie osobiste oraz poszanowanie innych.

\section{WNIOSKI}

Celem artykułu było ukazanie systemu wartości młodych, kończących szkołę podstawową i scharakteryzowanie tego systemu wartości przez pryzmat płci badanych, ich statusu materialnego, a także wielkości miejscowości zamieszkania i stopnia zaangażowania religijnego. Cel ten został osiągnięty, 
a postawiona hipoteza $\mathrm{H} 1$ potwierdziła się. Okazało się, że główne cele życiowe uczniów klas ósmych szkół podstawowych układają się w zhierarchizowany system wartości, wyznaczany poprzez takie cechy, jak płeć, sytuacja materialna rodziny, stopień zaangażowania religijnego, a także - chociaż w mniejszym stopniu - wielkość miejscowości zamieszkania.

Przedstawione wyniki wskazań młodzieży ósmych klas szkół podstawowych pozwalają stwierdzić, że młodzież na pierwszym miejscu ceni sobie wartości rodzinne i społeczne oraz konsumpcyjno-materialne, następnie religijno-etyczne oraz hedonistyczne. W dalszej kolejności młodzi ludzie cenią wartości witalno-perfekcjonistyczne i utylitarne. Na samym końcu hierarchii są wartości społecznie pożądane oraz patriotyczne i obywatelskie.

Zmienną, która w sposób wyraźny różnicuje wskazywane przez uczniów wybory, jest płeć respondentów. Dziewczęta częściej wskazują na wartości przyjacielskie, rodzinne i witalne, nie doceniając wartości religijnych i patriotycznych. Z kolei chłopcy wskazują na wartości materialne, patriotyczne, religijne, a swoje wybory drogi życiowej argumentują również spełnianiem ambicji swoich rodziców lub opiekunów. Jakkolwiek młodzież z rodzin dobrze sytuowanych wskazuje na wartości materialno-prestiżowe i zdaje się nie dostrzegać wartości religijnych, to młodzież ta w dużej części preferuje wartości społeczne, które są oparte na uczciwości i sprawiedliwości, a także rozwój osobisty. Uczniowie z rodzin najuboższych cenią sobie wartości religijne przy jednoczesnych dążeniach do realizowania tego, co według nich jest prestiżowe (życie pełne przygód, wrażeń, wyjazdy, podróże). Jakkolwiek niewielkie znaczenie odgrywa wielkość miejscowości zamieszkania respondentów, to można powiedzieć, że stopień zaangażowania religijnego już tak. Respondenci wierzący i praktykujący częściej wskazują na wartości rodzinne, przyjacielskie, a także religijne. Respondenci wierzący, lecz niepraktykujący także wskazują na wartości rodzinne i przyjacielskie, lecz podkreślają rolę wartości witalnych i materialnych. Z kolei ankietowani niewierzący częściej niż inni dążą do zaspokojenia potrzeb materialnych, hedonistycznych i utylitarnych.

Drugim celem artykułu było ukazanie, na ile dążenia i cele życiowe młodzieży układają się w bardziej ogólne modele wartości. Ten cel także został osiągnięty, a hipoteza $\mathrm{H} 2$ potwierdziła się. Okazało się, że główne cele życiowe uczniów klas ósmych szkół podstawowych, reprezentowane przez dwadzieścia osiem kategorii można sprowadzić do mniejszej liczby grup, które można nazwać wartościami, na które młode pokolenie, kończące szkołę podstawową zwraca szczególną uwagę w swoim życiu. 
Otrzymano, w wyniku analizy czynnikowej metodą głównych składowych, dziewięć wymiarów, które pozwalają stwierdzić, że owe 28 wskaźników grupuje się w dziewięć bardziej ogólnych, ale jednocześnie różnych od siebie grup wartości istotnych dla młodego pokolenia, kończącego szkołę podstawową. Zatem reasumując, można powiedzieć, że w systemie ważnych rzeczy czy też stanów psychospołecznych młodego pokolenia funkcjonują zarówno wartości etyczne, jak i konsumpcyjno-materialne, hedonistyczne, ukierunkowane na przyjemność ze względu na samo czerpanie przyjemności, jak też przyjemność czerpaną z miłości na całe życie oraz z przyjaźni. W systemie wartości młodego pokolenia znajdują się również wartości rodzinne oraz socjocentryczne i społecznie pożądane, a także religijne i perfekcjonistyczno-witalne.

\section{BIBLIOGRAFIA}

BŁASIAK, Anna. Młodzież- świat wartości. Kraków: Wyższa Szkoła Filozoficzno-Pedagogiczna „Ignatianum”-Wydawnictwo WAM, 2002.

BochEŃSKI, Józef. Sto zabobonów. Krótki filozoficzny słownik zabobonów. Kraków: Philed Sp. z o.o., 1994.

DyCZEWSKI, Leon. „System wartości w świadomości młodego pokolenia”. Roczniki Nauk Społecznych 8(3)(1980): 259-271

Dyczewski, Leon. Wartości w kulturze polskiej. Lublin: Fundacja Pomocy Szkołom Polskim na Wschodzie im. Tadeusza Goniewicza, 1993.

DYCZEWSKI, Leon. „Miejsce i funkcje wartości w kulturze”. W Kultura w kręgu wartości, redakcja Leon Dyczewski, 29-47. Towarzystwo Naukowe KUL, 2001.

DyCZEwski, Leon. „Wartości kulturowe ważne dla polskiej tożsamości”. W Tożsamość polska w odmiennych kontekstach. Tożsamość osób, zbiorowości, instytucji, redakcja Leon Dyczewski, Dariusz Wadowski, 149-179. Lublin: Wydawnictwo KUL, 2009.

DYCZEWSKI, Leon. Kultura w całościowym planie rozwoju. Warszawa: Instytut Wydawniczy Pax, 2011.

FolkiersKa, Andrea. „Typy wartości, ich miejsce i funkcjonowanie w kulturze”. W Młodzież a wartości, redakcja Hanna Świda-Ziemba, 92-134. Warszawa: Wydawnictwa Szkolne i Pedagogiczne, 1979.

GoldSCHMidT, Walter. „Values and the Field of Comparative Sociology”. American Sociological Review 18(3)(1951): 287-293.

GóRNIAK, Jarosław. „Analiza czynnikowa”. ASK (7)(1998): 83-102.

KLESZCZ, Magdalena i Małgorzata ŁĄCZYK. „Młodzież licealna wobec wartości, samotności i pasji”. Kraków-Katowice: Impuls, 2012.

MARIAŃSKI, Janusz. Moralność w okresie przemian. Warszawa: Instytut Wydawniczy PAX, 1990.

MARIAŃSKI, Janusz. W poszukiwaniu sensu życia: szkice socjologiczno-pastoralne. Lublin: Redakcja Wydawnictw KUL, 1990. 
MARIAŃSKI, Janusz. Młodzież między tradycją a ponowoczesnościa. Lublin: Redakcja Wydawnictw KUL, 1995.

MARIAŃSKI, Janusz. Przemiany moralności polskich maturzystów w latach 1994-2009. Lublin: Wydawnictwo KUL, 2011.

MARIAŃSKI, Janusz. „Wartości moralne w zmieniającym się społeczeństwie polskim”. Edukacja Humanistyczna 1(24)(2011): 15-17.

MARIAŃSKI, Janusz. „Świadomość moralna Polaków w procesie przemian - główne tendencje”. W Style życia, wartości, obyczaje. Stare tematy, nowe spojrzenia, redakcja Aldona Jawłowska, Wojciech Pawlik, Barbara Fatyga, 100-122. Lublin: Wydawnictwo UW, 2012.

MiszTal, Maria. Problematyka wartości w socjologii. Warszawa: Państwowe Wydawnictwo Naukowe, 1980.

NowAK, Stefan. „Postawy wartości aspiracje społeczeństwa polskiego. Przesłanki i prognozy na tle przemian dotychczasowych”. W Spoleczeństwo polskie czasu kryzysu, redakcja S. Nowak. Warszawa: Uniwersytet Warszawski, Instytut Socjologii, 1984.

OLEŚ, Piotr. Wartościowanie a osobowość. Lublin: Redakcja Wydawnictw KUL, 1989.

REALE, Giovanni. Historia filozofii starożytnej. Lublin: Wydawnictwo KUL, 2012.

RoDZIŃsKI, Adam. Na orbitach wartości. Lublin: Redakcja Wydawnictw KUL, 1989.

RószKIEwICZ, Małgorzata. Analiza klienta. Kraków: SPSS Polska, 2011.

STYK, Józef. „Orientacje wartościujące współczesnej młodzieży polskiej”. W Problemy współczesnej młodzieży w ujęciu nauk społecznych, redakcja Franciszka W. Wawro, 29-35. Lublin: Wydawnictwo KUL, 2007.

ŚwidA-ZIEMBA, Hanna. Młodzież a wartości. Warszawa, Wydawnictwa Szkolne i Pedagogiczne, 1979.

ŚWIDA-ZIEMBA, Hanna. Wartości egzystencjalne młodzieży lat dziewięćdziesiatych. Warszawa: Zakład Socjologii Moralności i Aksjologii Ogólnej, Instytut Stosowanych Nauk Społecznych, Uniwersytet Warszawski, 1988.

Thomas, I. William \& Florian ZnANIECKI. „Praktyka społeczna zdrowego rozsądku a teoria społeczna" (William I. ThOMAs, Florian ZNANIECKI, Chłop polski w Europie i Ameryce. Nota metodologiczna, 41-91. Warszawa: Ludowa Spółdzielnia Wydawnicza, 1976). W Socjologia ogólna. Wybór tekstów, redakcja Marian Malinkowski, Stanisław Marczuk, 165-334. Rzeszów: Wydawnictwo Wyższej Szkoły Pedagogicznej w Rzeszowie, 1986.

ZUZIAK, Władysław. „Czy aksjologia może przezwyciężyć ponowoczesny kryzys wartości?” Przeglad Filozoficzny - Nowa Seria 82(2)(2012): 295-310. https://doi.org/10.2478/v10271-0120058-6.

\section{CELE ŻYCIOWE MŁODZIEŻY KOŃCZĄCEJ SZKOŁĘ PODSTAWOWĄ. PRÓBA KLASYFIKACJI WARTOŚCI MŁODEGO POKOLENIA}

\section{Streszczenie}

Wartości jako materialne oraz niematerialne cenności dla człowieka lub grupy ludzi stanowią podstawowy element rzeczywistości społecznej, w której człowiek wzrasta i kształtuje się jako istota społeczna. Obecnie w literaturze przedmiotu często mówi się o kryzysie wartości, współistnieniu wielu równorzędnych, wzajemnie się wykluczających wartości, jak również permisywizmie wartości. 
Artykuł podejmuje próbę ukazania systemu wartości uczniów klas ósmych szkół podstawowych. Chodzi o odpowiedź na pytanie, czy wartości układają się w jakieś bardziej ogólne modele i jakie są to modele? Badanie było realizowane za pomocą autorskiego kwestionariusza ankiety internetowej (CAWI) wypełnianego audytoryjnie w dniach 1.10.2018 r. - 12.01.2019 r. Badaną próbę stanowiło 70185 uczniów z terenu Polski. Następnie respondenci zostali odlosowani do reprezentatywnej, w skali kraju, liczby 8530 uczniów, spośród których ósmioklasiści reprezentowani byli przez 1986 respondentów.

Wyniki badań pozwalają stwierdzić, że główne cele życiowe respondentów układają się w zhierarchizowany system wartości, wyznaczany poprzez takie cechy jak płeć, sytuacja materialna rodziny, stopień zaangażowania religijnego, wielkość miejscowości zamieszkania. Ponadto cele życiowe badanych można sprowadzić do mniejszej liczby grup, które można nazwać grupami wartości. Zatem w systemie ważnych wartości młodego pokolenia funkcjonują wartości etyczne, konsumpcyjno-materialne, hedonistyczne, ale także rodzinne, socjocentryczne i społecznie pożądane, religijne i perfekcjonistyczno-witalne.

Słowa kluczowe: wartości; modele wartości; cele życiowe; młodzież; styl życia.

\section{LIFE GOALS FOR YOUNG PEOPLE LEAVING PRIMARY SCHOOL. TRYING TO CLASSIFY THE VALUE OF THE YOUNGER GENERATION}

\section{Summary}

Values as tangible and non-tangible valuables for a man or for a group of people constitute the basic element of social reality, in which a person grows up and is formed as a social being. Currently the subject literature frequently refers to a crisis of values, co-existence of many equivalent, mutually exclusive values, as well as to the permissiveness of values.

The article is an attempt at presenting the system of values in eighth-form primary school students. It is about answering the question whether the values are arranged in certain more general models and what sort of models are these? The study was performed with the use of an original online questionnaire (CAWI) completed in an auditorium between 1st October 2018 and 12th January 2019. The examined trial group (array) consisted of 70185 school students from the area of Poland. Then the respondents were voted-off to the number, which is representative in the scale of the country - 8530 students, from among whom the eighth-formers were represented by 1986 respondents.

The study results allow to find that the main aims in the lives of the respondents are arranged in a hierarchy of values, determined by such features as gender, the family's financial situation, degree of religious commitment, size of the place of residence. Besiders, the living goals of the examinees can be reduced to a smaller number of groups that can be called the groups of values. Thus, in the system of values important for the young generation there are ethical, consumeristmaterial and hedonist values, but also family, socio-metrical, socially desirable, religious and perfectionist-vital values.

Key words: values; value models; life goals; youth; lifestyle. 